A. A. Uritskaya ${ }^{1}$, N. S. Kozhevnikova ${ }^{2}$, T. V. Yakubova ${ }^{3}$

${ }^{1}$ Ural Federal University, 19 Mira St., 620002 Ekaterinburg, Russia ${ }^{2}$ Institute of Solid State Chemistry UrB RAS, 91 Pervomaiskaya St., 620990 Ekaterinburg, Russia ${ }^{3}$ Ural Institute of state fire service of EMERCOM of Russia, 22 Mira St., 620002 Ekaterinburg, Russia Tel.: (343) 362-35-64 e-mail: kozhevnikova@ihim.uran.ru

\title{
Kinetics of chemical bath deposition of zinc sulfide $\mathrm{ZnS}$ *
}

The paper is devoted to kinetic methods of chemical bath deposition of zinc sulfide $\mathrm{ZnS}$ from aqueous alkaline solutions containing ehylenediamine complex zinc salt $\mathrm{Zn}(\mathrm{En})_{n}{ }^{2+}$ and diamide of thiocarbonic acid $\mathrm{N}_{2} \mathrm{H}_{4} \mathrm{CS}$. It is established that the rate of formation of $\mathrm{ZnS}$ is weakly dependent on $\mathrm{pH}$, depends on the concentration of the precipitant $\left(\left(\mathrm{N}_{2} \mathrm{H}_{4} \mathrm{CS}\right)\right.$ and decreases with increasing concentration of ligand (ethylenediamine). The calculation of the theoretical curves on the experimentally obtained kinetic equation shows a satisfactory description of experimental data that allows to recommend it to calculate the rate of formation of $\mathrm{ZnS}$ in aqueous alkaline solutions of $\mathrm{N}_{2} \mathrm{H}_{4} \mathrm{CS}$.

Key words: chemical bath deposition, thiourea, ethylenediamine, detectors of ultraviolet radiation, the apparent rate constant of the reaction, the true rate constant of the reaction

*This work was done under financial support from RFBR (Project 16-03-00566).

А. А. Урицкая,

Н. С. Кожевникова, Т. В. Якубова

\section{Кинетика химического осаждения сульфида цинка ZnS*}

Работа посвящена исследованию кинетическими методами химического осаждения сульфида цинка ZnS из водных щелочных растворов, содержащих этилендиаминовую комплексную соль цинка $\mathrm{Zn}(\mathrm{En})_{n}^{2+}$ и диамид тиоугольной кислоты $\mathrm{N}_{2} \mathrm{H}_{4} \mathrm{CS}$. Установлено, что скорость образования ZnS слабо зависит от величины pH, зависит от концентрации осадителя $\left(\mathrm{N}_{2} \mathrm{H}_{4} \mathrm{CS}\right)$ и уменьшается с увеличением концентрации лиганда (этилендиамина). Расчет теоретических кривых по полученному экспериментально кинетическому уравнению показывает удовлетворительное описание полученных экспериментальных данных, что позволяет рекомендовать его для расчета скорости образования $\mathrm{ZnS}$ в водных щелочных растворах $\mathrm{N}_{2} \mathrm{H}_{4} \mathrm{CS}$.

Ключевые слова: химическое осаждение; тиомочевина; этилендиамин; детекторы ультрафиолетового излучения; кажущаяся константа скорости реакции; истинная константа скорости реакции.

* Работа выполнена при финансовой поддержке РФФИ (Проект № 16-03-00566).

(c) Uritskaya A. A., Kozhevnikova N. S., Yakubova T. V., 2016 


\section{Introduction}

Zinc sulfide $\mathrm{ZnS}$, being one of the most important representatives of the wide-band-gap semiconductors, is studied intensively in recent time as a promising material for the creation of detectors of ultraviolet radiation [1]. $\mathrm{ZnS}$ is one of the first [2] and important compounds used as matrix for phosphors [3]. $\mathrm{ZnS}$ doped with ions of transition metals $\left(\left(\mathrm{Mn}^{2+}, \mathrm{Cu}^{2+}\right)\right.$ allows us to observe the luminescence under the influence of radiation with higher energies, e.g. $\mathrm{x}$-ray and ultraviolet $[4,5]$. The interest in $\mathrm{ZnS}$ as the optical material for photonic crystals is determined by its properties: high values of integral transmittance $(\sim 0.72)$ in the range 400-14000 $\mathrm{nm}$ and the refractive index (2.3 at a wavelength of $1 \mu \mathrm{m})$ [6, 7]. In this regard, a large number of works were devoted and dedicated to the synthesis of $\mathrm{ZnS}[8,9]$. Among many problems in the synthesis of new compounds there is one of the most important. It's determination of the flow rate of the transformations in the studied systems. The knowledge of the rate of chemical reaction allows creating technological scheme of production of new materials without solving complex problems of the reaction mechanism. The rate of any chemical reaction is determined experimentally [10].

The present work is devoted to study of kinetic methods of chemical deposition of zinc sulfide $\mathrm{ZnS}$ from aqueous alkaline solutions containing ehylenediamine complex zinc salt $\mathrm{Zn}(\mathrm{En})_{\mathrm{n}}{ }^{2+}$ and diamide of thiocarbonic acid $\mathrm{N}_{2} \mathrm{H}_{4} \mathrm{CS}$. With the introduction of $\mathrm{N}_{2} \mathrm{H}_{4} \mathrm{CS}$ in the solution of complex salt of zinc the formation of a solid phase $\mathrm{ZnS}$ begins according to reaction:

$$
\begin{aligned}
& \mathrm{Zn}(\mathrm{En})_{\mathrm{n}}^{2+}+\mathrm{N}_{2} \mathrm{H}_{4} \mathrm{CS}+2 \mathrm{OH}^{-}= \\
& =\mathrm{ZnS}+\mathrm{nEn}+\mathrm{H}_{2} \mathrm{CN}_{2}+2 \mathrm{H}_{2} \mathrm{O} .
\end{aligned}
$$

Previously it was found $[11,12]$ that chemical precipitation of sulphides of metals from solutions of thiourea is a heterogeneous autocatalytic process. And the surface of the metal sulfide formed in the reaction is the catalyst of this process. Therefore describing the kinetics of the process (1) in this article we proceeded from the assumption that the formation of $\mathrm{ZnS}$ can also be viewed as a heterogeneous process. In this paper we have confined the study of formal kinetic regularities.

For the compilation of the kinetic equation it is necessary to determine the reaction order for each precursor. In application to heterogeneous catalytic processes we distinguish the true and apparent reaction order. True order is an order of the reaction regarding concentration of reagents on the surface of the solid phase and apparent order is the order of reaction with respect to varying volumetric concentrations of reagents in solution. In this work we determined the apparent orders of reaction (1) on the components. A formal kinetic equation for the rate $w$ of process (1) can be written as follows:

$$
\begin{aligned}
& w=k_{0} \exp (-E / R T) \times \\
& \times S C_{E n}^{n_{1}} C_{T M}^{n_{2}} C_{\mathrm{OH}^{-}}^{n_{3}} C_{\mathrm{Zn}^{2+}}^{n_{4}},
\end{aligned}
$$

where $C_{E n}, C_{T M}, C_{\mathrm{OH}^{-}}, C_{\mathrm{Zn}^{2+}}$ are the current concentrations of reaction mixture components; $n_{1}, n_{2}, n_{3}, n_{4}$ are the kinetic orders of reaction by components: ethylenediamine, thiourea, alkali, salts of zinc, respectively; $S$ is the surface of the solid phase on which the formation of $\mathrm{ZnS}$ occurs; $k_{0}$ is the pre-exponential factor; $E$ is activation energy; $R$ is universal gas constant; $T$ is temperature, $\mathrm{K}$.

At the kinetic description the rate of the heterogeneous process depends not 
only on the concentration of reactants, $\mathrm{pH}$ value, temperature, which are easily measurable, but on the size of the surface of the solid phase which is continuously changing during the process due to nu-

\section{The experimental part}

When conducting kinetic study the concentrations of the solutions were the following, $\mathrm{mol} / \mathrm{l}:\left[\mathrm{ZnSO}_{4}\right]=0.5,[\mathrm{En}]=5.0$, $\left[\mathrm{N}_{2} \mathrm{H}_{4} \mathrm{CS}\right]=0.5,[\mathrm{NaOH}]=1-4$. The concentration of the precursors in the reaction mixtures was ranged: $\mathrm{mol} / \mathrm{l}$ : $\left[\mathrm{ZnSO}_{4}\right]=0.008-0.020,[\mathrm{En}]=0.10-0.25$, $\left[\mathrm{N}_{2} \mathrm{H}_{4} \mathrm{CS}\right]=0.08-0.20, \mathrm{pH}=11.5-12.5$. With the aim of obtaining reproducible results the order of merging reagents has passed. The calculated volume of $\mathrm{ZnSO}_{4}$ solution was poured into volumetric flask, En and water were added. The set value of $\mathrm{pH}$ was adjusted by the introduction of $\mathrm{NaOH}$ and then a solution of $\mathrm{N}_{2} \mathrm{H}_{4} \mathrm{CS}$ was added. The reaction mixture was prepared at room temperature. At the next phase the solid phase with known surface value, which was created by the introduction of glass powder of sodium borosilicate composition into the reactor was added in the reaction mixture [13]. The glass powder was prepared in the laboratory according to the method described previously [14]. The obtained glass powder had a median particle size of $50 \mu \mathrm{m}$ and a size of specific surface area of $24.5 \mathrm{~m}^{2} / \mathrm{kg}$ calculated from the known density of the glass $2450 \mathrm{~kg} / \mathrm{m}^{3}$ [13]. The hitch of glass powder, $0.1 \mathrm{~kg}$ per 1 liter of solution, allowed localizing the process on the surface of the glass, i.e. eliminating the $\mathrm{ZnS}$ nucleation in the volume of the reaction solution was installed by the preliminary series of experiments [14]. The glass powder was preliminarily coated with a film of $\mathrm{ZnS}$. To maintain cleation, coagulation and sedimentation of the solid phase. Therefore the study of the kinetic of the process (1) was conducted using pre-introduced solid phase with known surface value.

particles in a suspended state, the process (1) was carried out under continuous stirring with a stirrer with flexible drive with a speed of $300 \mathrm{Rev} / \mathrm{min}$. To determine the order of reaction (1) on components the method of Ostwald-Neues was used [15]. For this purpose the conditions were created under which in reaction (1) the concentration of only one component would change and the concentrations of all other substances participating in the reaction were set in excess and their changes in time can be neglected. Therefore equation (2) at a given temperature can be represented in the form:

$$
w=k_{\text {exp }} C_{\mathrm{Zn}^{2+}}^{n_{4}},
$$

where $k_{\text {exp }}=k^{\prime} S C_{E n}^{n_{1}} C_{T M}^{n_{2}} C_{\mathrm{OH}^{-}}^{n_{3}}$ is the apparent rate constant of the reaction, $k^{\prime}$ is the true rate constant of reaction per unit surface $\mathrm{ZnS}$ and the unit of concentration of components with respect to orders of the reaction.

Equation (3) proved that to determine the reaction rate $\mathrm{w}$ it was sufficient to take down experimentally the dependence of concentrations of ions $\mathrm{Zn}^{2+}$ on time in different reaction solutions. The measurement of concentrations of ions $\mathrm{Zn}^{2+}$ was produced by the method of sampling from the reactor by chemical-analytical way, i.e. using complexometric direct titration with visual indication of the equivalence point by using an indicator eriochrome black $\mathrm{T}$ in a mixture with sodium chloride at $\mathrm{pH}=10$. To maintain a 
constant temperature during the reaction (1) a liquid thermostat with a temperature support stability of 0.1 degrees was used. The control of $\mathrm{pH}$ was performed using pH meter Hanna Instruments HI 98130 with accuracy of the measurement of $\mathrm{pH}$ equal to 0.02 .

The mathematical treatment of kinetic curves obtained in the conditions when only one of the system parameters was changing while other parameters were constant (for example, the En concentration changes at constant concentrations $\mathrm{N}_{2} \mathrm{H}_{4} \mathrm{CS}, \mathrm{pH}$, temperature and degree of loading of the glass powder), allowed to determine the reaction rate constant under different conditions, as well as private orders of reaction (1) on components. The process (1) was controlled to achieve the equilibrium corresponding to the appearance of the horizontal section on the kinetic curve. The kinetic curves were de- scribed by the equation of two-sided reaction of first order.

$$
\lg \frac{x_{\infty}}{x_{\infty}-x}=\frac{\left(k_{p r}+k_{\text {form }}\right)}{2.3} \tau,
$$

where $x_{\infty}, x$ are the number of complex salt $\mathrm{Zn}(\mathrm{En})_{n}{ }^{2+}$ converted to the sulfide by the time to reach equilibrium and any time $\tau$, respectively; $k_{p r}$ is the rate constant of the process of formation of $\mathrm{ZnS} ; k_{\text {form }}$ is the rate constant of the decay process of $\mathrm{ZnS}$.

The graphical solution of the equation (4) is a straight line in the coordinates $\lg \left(x_{\infty} /\left(x_{\infty}-x\right)\right)-\tau$ with an angular coefficient $a$, equal to the sum of the constants of direct $k_{p r}$ and reverse $k_{\text {form }}$ reactions (fig. 2). To find the rate constant for the reaction of formation of $\mathrm{ZnS} k_{p r}$ the ratio characterizing the equilibrium state $k_{p r} / k_{\text {form }}=x_{\infty} /\left(C_{0}-x_{\infty}\right)$ was used, where $C_{0}$ is the initial concentration of $\mathrm{ZnSO}_{4}$ in solution.

\section{Results and discussion}

The typical kinetic curves, taken off in the conditions of the controlled surface at a temperature $363 \mathrm{~K}$, initial concentration $\left[\mathrm{N}_{2} \mathrm{H}_{4} \mathrm{CS}\right]=0.1 \mathrm{~mol} / \mathrm{l}$ and $и$ $S=24500 \mathrm{sm}^{2} / 1$ are presented on a fig. 1 .

The process of formation of $\mathrm{ZnS}$ was considered complete, when the equilibrium value of remaining concentration of salt of zinc at in solution was arrived: it's horizontal area on a kinetic curve. The results of graphic calculation of $k_{p r}$ and $k_{\text {form }}$ of reaction (1) for the concentrations of En 0.15 and $0.20 \mathrm{~mol} / \mathrm{l}$. The results of calculation of $k_{p r}$ and $k_{\text {form }}$ for the concentrations of En $0.1,0.15,0.20$ and 0.25 the mol/l show that with the increase of concentration of En $k_{\mathrm{pr}}$ diminishes, consequently, the rate of reaction diminishes (fig. 2). The concentration of free ions of $\mathrm{Zn}^{2+}$ diminishes with the increase of concentration of complexing agent that slows rate of reaction.

On the experimental values of $k_{\mathrm{pr}}$ at the different initial concentrations of $\mathrm{ZnSO}_{4}$, En, $\mathrm{N}_{2} \mathrm{H}_{4} \mathrm{CS}, \mathrm{ZnSO}_{4}$, En and $\mathrm{pH}$ it is possible to define the order of reaction on every component. The calculation of kinetic orders of reaction on components was conducted on equalization $\lg k_{p r}=\lg k_{i}+$ $+n \lg C_{i}$ which in co-ordinates $\lg k_{p r}-\lg C_{i}$ presents a straight line with the angular coefficient of $n_{i}$. The graphic decision of this equalization for determination of orders of reaction on components of En, $\mathrm{N}_{2} \mathrm{H}_{4} \mathrm{CS}$ and $\mathrm{NAOH}$ is presented on a fig. 3-5. 
Thus, it is set as a result of kinetic researches that rate of reaction (1) is proportional the concentrations of components of reactionary solution, which are included in kinetic equalization with the followings indexes of degree:

On the found values of seeming constant of rate the veritable constant of rate

\begin{tabular}{l|c|c|c|c}
\multicolumn{1}{c|}{ Component } & $\mathrm{ZnSO}_{4}$ & En & $\mathrm{N}_{2} \mathrm{H}_{4} \mathrm{CS}$ & $\mathrm{NaOH}$ \\
\hline $\begin{array}{l}\text { The seeming private order of reaction } \\
\text { (1) on the component of } n_{i}\end{array}$ & 1.0 & -1.9 & 1.2 & 0.3
\end{tabular}

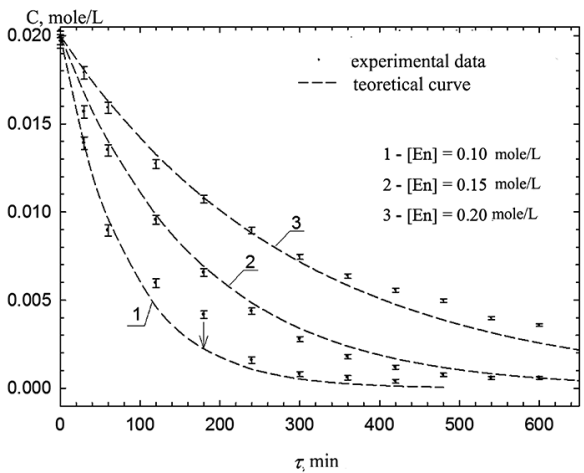

Fig. 1. The dependence of rate of reaction of formation of $\mathrm{ZnS}$ on the concentration of ethylenediamine En. The kinetic curves are taken off in the conditions of the known surface of $S=24500 \mathrm{sm}^{2} / \mathrm{l}$ at a temperature

$363 \mathrm{~K}$ and initial concentration $\left[\mathrm{N}_{2} \mathrm{H}_{4} \mathrm{CS}\right]=0.1 \mathrm{~mol} / \mathrm{l}$. Theoretical curves are expected on equalization (6)

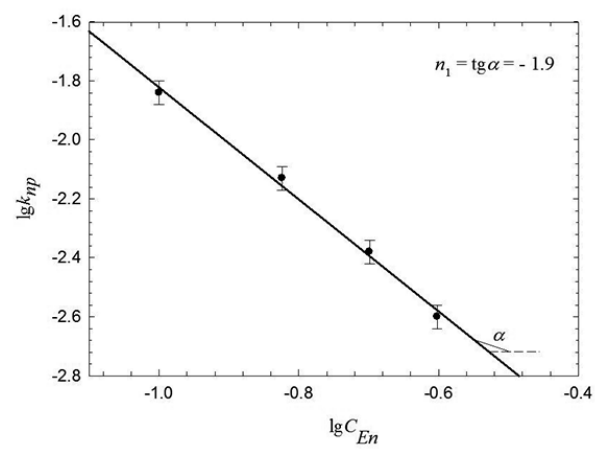

Fig. 3. The graphic determination of private order $n_{1}$ of reaction of formation of $\mathrm{ZnS}$

(1) on ehylenediamine. A reaction was conducted in the conditions of the known surface of $S=24500 \mathrm{sm}^{2} / 1$ at a temperature $363 \mathrm{~K}$ and $и\left[\mathrm{~N}_{2} \mathrm{H}_{4} \mathrm{CS}\right]=0.1 \mathrm{~mol} / \mathrm{l}$

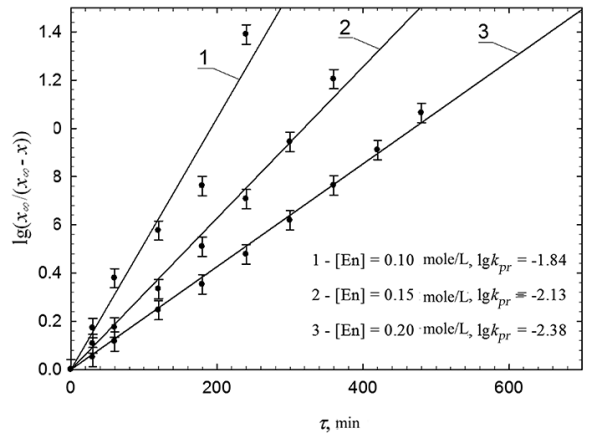

Fig. 2. The graphic determination of constants of rate of $k_{p r}$ and $k_{\text {form }}$ of process (1) on equalization of two-sided reaction of the first order (4). A process (1) was conducted in the conditions of the known surface of $S=24500 \mathrm{sm}^{2} / 1$ at a temperature $363 \mathrm{~K}$ and $\left[\mathrm{N}_{2} \mathrm{H}_{4} \mathrm{CS}\right]=0.1 \mathrm{~mol} / \mathrm{l}$

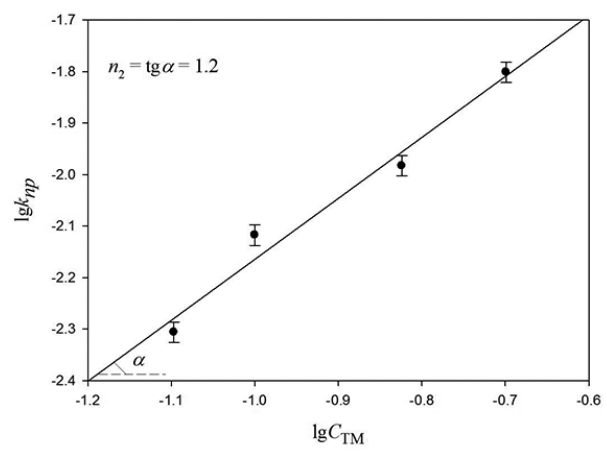

Fig. 4. The graphic determination of private order $n_{2}$ of reaction of formation of $\mathrm{ZnS}$ (1) on thiourea. A reaction was conducted in the conditions of the known surface of $S=24500 \mathrm{sm}^{2} / 1$ at a temperature $363 \mathrm{~K}$ and $[\mathrm{En}]=0.15 \mathrm{~mol} / \mathrm{l}$ 
of heterogeneous reaction of formation of $\mathrm{ZnS}$ was calculated at a temperature $363 \mathrm{~K}$, attributed to unit of surface of hard phase of $\mathrm{ZnS}$ and unit of concentrations of every component taking into account the private orders of reaction:

$$
k^{\prime}=\frac{k_{e x p}}{S C_{E n}^{-1.9} C_{T M}^{1.2} C_{\mathrm{OH}^{-}}^{0.3}} .
$$

The data got on equalization (5) show that at the changing concentrations of components of reaction rate of reaction mixture $k^{\prime}$ remain permanent within the limits of error of experiment. The mean value $k^{\prime}$ make $(3.69 \pm 0.13)$. $\cdot 10^{-7} \mathrm{l}^{0.6} \cdot \mathrm{mol}^{0.4} \cdot \mathrm{min}^{-1} \cdot \mathrm{sm}^{-2}$ under $363 \mathrm{~K}$.

To determine the experimental dependence of reaction rate of sulphide formation on temperature the series of experiments were conducted at temperatures 358, 363 and $369 \mathrm{~K}$, that allowed graphically (fig. 6) determination of activation energy of process by Arrhenius equation: $\lg k^{\prime}=\lg k_{0}-(E / 2.3 R T)$ which made $E=84.5 \pm 0.5 \mathrm{~kJ} / \mathrm{mol}$.

The found value of activation energy showed that the process of formation of $\mathrm{ZnS}$ in the system was not limited by the stage of diffusion as for diffusive processes the small values of energy of activating are from 8 to $30 \mathrm{~kJ} / \mathrm{mol}$ [15]. The pre-exponential multiplier of equalization of Arrhenius is expected on the veritable rate constant at $363 \mathrm{~K}$ and at the known value of energy of activating of $E$ : $k_{0}=5.39 \cdot 10^{5} \mathrm{~mol}^{0.4}{ }^{0.6} \mathrm{sm}^{-2} \mathrm{~min}^{-1}$.

It is set as a result of the conducted research, that the process of formation of $\mathrm{ZnS}(1)$ is described formal kinetic equalization:

$$
\begin{aligned}
w & =5.39 \cdot 10^{5} \exp \left(-\frac{84500}{8.3147}\right) \times \\
& \times S C_{E n}^{-1.9} C_{T M}^{1.2} C_{\mathrm{OH}^{-}}^{0.3}\left(C_{0}-x\right) .
\end{aligned}
$$

\section{Conclusion}

Thus, in the terms chosen in this work the rate of process (1) depends weakly

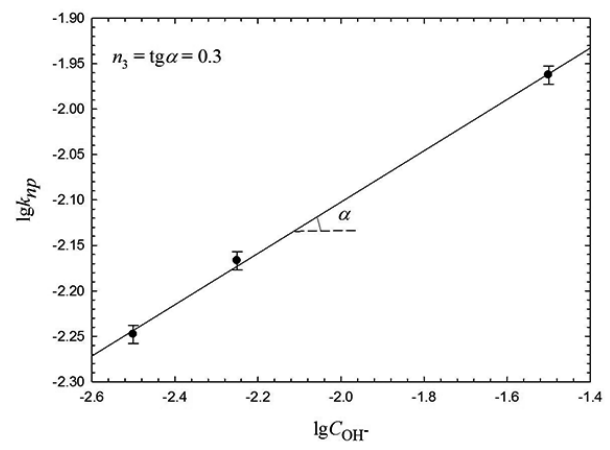

Fig. 5. The graphic determination of private order $n_{3}$ of reaction of formation of $\mathrm{ZnS}$ (1) to on $\mathrm{OH}^{-}$-ions. A reaction was conducted in the conditions of the known surface of $S=24500 \mathrm{sm}^{2} / 1$ at a temperature $363 \mathrm{~K}$ and $\left[\mathrm{N}_{2} \mathrm{H}_{4} \mathrm{CS}\right]=0.1 \mathrm{~mol} / \mathrm{l}$ on the size of $\mathrm{pH}$ that is explained by the buffer action of ethylenediamine, depends on the concentration of precipita-

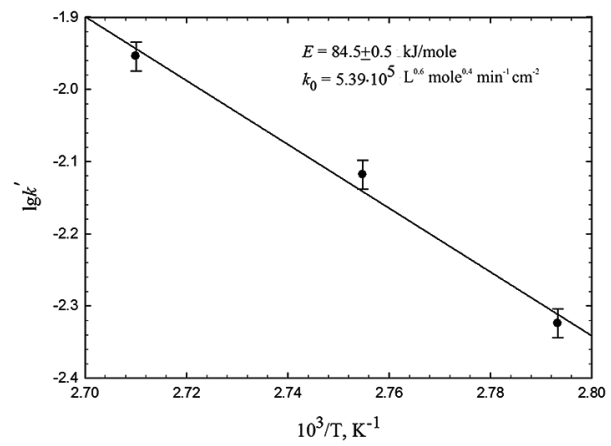

Fig. 6. Graphic calculation of energy of activating of process of the chemical precipitation of $\mathrm{ZnS}$ (1) on equalization of Arrhenius 
tor (thiourea) and diminishes with the increase of concentration of ligand (ethylenediamine) from the decline of concentration of free ions of zinc in solution. The calculation of theoretical kinetic curves on equalization (8) shows satisfactory definition of the got experimental data (fig. 1), that allows recommending it for the calculation of formation rate of $\mathrm{ZnS}$ in water alkaline solutions of diamide of thiocarbonic acid.

\section{In russian}

\section{Введение}

Сульфид цинка $\mathrm{ZnS}$, являясь одним из важнейших представителей широкозонных полупроводников, интенсивно исследуется в последнее время как перспективный материал для создания детекторов ультрафиолетового излучения [1]. $\mathrm{ZnS}$ - одно из самых первых [2] и важных соединений, использующихся в качестве матрицы для люминофоров [3]. Допирование $\mathrm{ZnS}$ ионами переходных металлов $\left(\mathrm{Mn}^{2+}\right.$, $\mathrm{Cu}^{2+}$ ) позволяет наблюдать люминесценцию под воздействием излучений с повышенными энергиями, например рентгеновского и ультрафиолетового $[4,5]$. Интерес к $\mathrm{ZnS}$ как к оптическому материалу для фотонных кристаллов определяется его свойствами: высокими значениями интегрального пропускания $(\sim 0,72)$ в диапазоне $400-$ 14000 нм и коэффициента преломления (2,3 при длине волны 1 мкм) [6, 7]. В связи с этим большое количество работ посвящалось и посвящается синтезу ZnS $[8,9]$. Среди многих проблем при синтезе новых соединений существует одна из важнейших определение скорости протекания превращений в изучаемых системах. Знание скорости превращения позволяет создавать технологические схемы производства новых материалов, не решая сложных вопросов о механизме реакций. Скорость любой химической реакции определяется экспериментальным путем [10].

Настоящая работа посвящена исследованию кинетическими методами процесса химического осаждения сульфида цинка $\mathrm{ZnS}$ из водных щелочных растворов, содержащих этилендиаминовую комплексную соль цинка $\mathrm{Zn}(\mathrm{En}){ }_{n}^{2+}$ и диамид тиоугольной кислоты (тиомочевину) $\mathrm{N}_{2} \mathrm{H}_{4} \mathrm{CS}$. При введении $\mathrm{N}_{2} \mathrm{H}_{4} \mathrm{CS}$ в раствор комплексной соли цинка, начинается образование твердой фазы $\mathrm{ZnS}$ по реакции:

$$
\begin{aligned}
& \mathrm{Zn}(\mathrm{En})_{\mathrm{n}}{ }^{2+}+\mathrm{N}_{2} \mathrm{H}_{4} \mathrm{CS}+2 \mathrm{OH}^{-}= \\
& =\mathrm{ZnS}+\mathrm{nEn}+\mathrm{H}_{2} \mathrm{CN}_{2}+2 \mathrm{H}_{2} \mathrm{O} .
\end{aligned}
$$

Ранее было установлено, что химическое осаждение сульфидов металлов из растворов тиомочевины является гетерогенным автокаталитическим процессом [11, 12]. А поверхность сульфида металла, образующегося в результате реакции, является катализатором этого процесса. Поэтому при кинетическом описании процесса (1) в данной работе исходили из предположения, что формирование $\mathrm{ZnS}$ также можно рассматривать как гетерогенный процесс. В данной работе мы ограничились исследованием формальных кинетических закономерностей.

Для составления кинетического уравнения необходимо определить по- 
рядок реакции по каждому исходному компоненту. В применении к гетерогенным каталитическим процессам различают истинный и кажущийся порядок реакции, понимая под истинным порядок реакции относительно концентрации реагентов на поверхности твердой фазы, а кажущийся - порядок реакции по отношению к объемным изменяющимся концентрациям реагентов в растворе. Определены кажущиеся порядки реакции (1) по компонентам. Формальное кинетическое уравнение скорости $w$ процесса (1) можно записать следующим образом:

$$
\begin{aligned}
& w=k_{0} \exp (-E / R T) \times \\
& \times S C_{E n}^{n_{1}} C_{T M}^{n_{2}} C_{\mathrm{OH}^{-}}^{n_{3}} C_{\mathrm{Zn}^{2+}}^{n_{4}},
\end{aligned}
$$

где $C_{E n}, C_{T M}, C_{\mathrm{OH}^{-}}, C_{\mathrm{Zn}^{2+}}-$ текущие концентрации компонентов реакционной смеси; $n_{1}, n_{2}, n_{3}, n_{4}$ - кинетические порядки реакции по компонентам, эти- лендиамину, тиомочевине, щелочи, соли цинка, соответственно; $S$ - поверхность твердой фазы, на которой происходит образование $\mathrm{ZnS} ; k_{0}$ - предэкспоненциальный множитель; $E$ энергия активации процесса; $R$ - универсальная газовая постоянная; $T$ температура, К.

При кинетическом описании скорость гетерогенного процесса определяется не только концентрацией реагентов, величиной $\mathrm{pH}$, температурой, которые легко измеримы, но и величиной поверхности твердой фазы, непрерывно изменяющейся в ходе процесса за счет зарождения, коагуляции и седиментации частиц твердой фазы. Поэтому изучение кинетики процесса (1) проводили в условиях специально вводимой контролируемой поверхности твердой фазы.

\section{Экспериментальная часть}

При проведении кинетических исследований концентрации исходных растворов были следующие, моль/л: $\left[\mathrm{ZnSO}_{4}\right]=0,5,[\mathrm{En}]=5,0,\left[\mathrm{~N}_{2} \mathrm{H}_{4} \mathrm{CS}\right]=0,5$, $[\mathrm{NaOH}]=1-4$. Концентрации компонентов в реакционных смесях варьировали в пределах, моль/л: $\left[\mathrm{ZnSO}_{4}\right]=$ $=0,008-0,020,[\mathrm{En}]=0,10-0,25,\left[\mathrm{~N}_{2} \mathrm{H}_{4} \mathrm{CS}\right]=$ $=0,08-0,20, \mathrm{pH}=11,5-12,5$. С целью получения воспроизводимых результатов выдерживали порядок сливания реагентов. В мерную колбу вливался рассчитанный объем раствора $\mathrm{ZnSO}_{4}$, добавлялся En и вода. Заданная величина $\mathrm{pH}$ корректировалась введением раствора $\mathrm{NaOH}$, и затем добавлялся раствор $\mathrm{N}_{2} \mathrm{H}_{4} \mathrm{CS}$. Реакционная смесь готовилась при комнатной температуре. На следующем этапе в реакционную смесь вводили контролируемую поверхность твердой фазы, которую создавали введением в реактор стеклянного порошка натрий боросиликатного состава [13]. Стеклянный порошок готовился в лабораторных условиях по методике, описанной ранее [14]. Полученный стеклянный порошок имел средний размер частиц 50 мкм и величину удельной поверхности $24,5 \mathrm{~m}^{2} / \kappa г$, рассчитанную по известной плотности стекла $2450 \mathrm{\kappa г} / \mathrm{M}^{3}$ [13]. Предварительной серией экспериментов [14] была установлена навеска стеклянного порошка, равная 0,1 кг на 1 л раствора, позволяющая локализовать процесс на поверхности стекла, т. е. исключить зарождение $\mathrm{ZnS}$ в объеме реакционного раствора. Стеклянный порошок предварительно покрывали 
пленкой ZnS. Для поддержания частиц во взвешенном состоянии процесс (1) проводили при непрерывном перемешивании с помощью мешалки с гибким приводом со скоростью 300 об/мин.

Для определения порядка реакции (1) по компонентам использовали метод Оствальда - Нойеса [15]. Для этого создавали такие условия, при которых в реакции (1) изменялась бы концентрация только данного компонента, а концентрации всех остальных веществ участников реакции задавались в избытке, и изменением их во времени можно было пренебречь. Следовательно, уравнение (2) при заданной температуре можно представить в виде:

$$
w=k_{\text {эксп }} C_{\mathrm{Zn}^{2+}}^{n_{4}},
$$

где $k_{\text {эксп }}=k^{\prime} S C_{E n}^{n_{1}} C_{T M}^{n_{2}} C_{\mathrm{OH}^{-}}^{n_{3}}-$ кажущаяся константа скорости реакции, $k^{\prime}$ - истинная константа скорости реакции, отнесенная к единице поверхности $\mathrm{ZnS}$ и единице концентрации компонентов с учетом порядков реакции по компонентам.

Анализируя уравнение (3), видно, что для определения скорости реакции $w$ достаточно экспериментальным путем снять зависимость концентрации ионов $\mathrm{Zn}^{2+}$ от времени в различных реакционных растворах. Измерение концентрации ионов $\mathrm{Zn}^{2+}$ произведено методом отбора проб из реактора химико-аналитическим путем, т.е. с использованием прямого комплексонометрического титрования с визуальной индикацией точки эквивалентности с помощью индикатора эриохрома черного Т в смеси с хлоридом натрия при $\mathrm{pH}=10$. Для поддержания постоянной температуры в ходе реакции (1) использовали жидкостный термостат со стабильностью поддержания температуры 0,1 градуса. Контроль за величиной $\mathrm{pH}$ осуществляли с помощью измерителя $\mathrm{pH}$ Hanna Instruments $\mathrm{HI}$ 98130 с точностью измерения величины рН, равной 0,02 .

Математическая обработка кинетических кривых, полученных в условиях, когда меняется только один из параметров системы при неизменных остальных (например, меняется концентрация Еn при постоянных значениях концентрации $\mathrm{N}_{2} \mathrm{H}_{4} \mathrm{CS}, \mathrm{pH}$, температуры и степени загрузки стеклянного порошка), позволила определить константы скорости реакции в разных условиях, а также частные порядки реакции (1) по компонентам. Процесс (1) контролировали до достижения равновесия, соответствующего появлению горизонтального участка на кинетической кривой. Кинетические кривые описывались уравнением двухсторонней реакции первого порядка:

$$
\lg \frac{x_{\infty}}{x_{\infty}-x}=\frac{\left(k_{\text {пр }}+k_{\text {обр }}\right)}{2,3} \tau,
$$

где $x_{\infty}, x$ - количества комплексной соли $\mathrm{Zn}(\mathrm{En})_{n}{ }^{2+}$, перешедшей в сульфид ко времени достижения равновесия и к любому моменту времени $\tau$, соответственно; $k_{\text {пр }}$ - константа скорости процесса образования ZnS; $k_{\text {обр }}$ - константа скорости процесса распада ZnS.

Графическим решением уравнения (4) является прямая линия в координатах $\lg \left(x_{\infty} /\left(x_{\infty}-x\right)\right)-\tau$ с угловым коэффициентом $a$, равным сумме констант прямой $k_{\text {пр }}$ и обратной $k_{\text {обр }}$ реакций (рис. 2). Для нахождения константы скорости реакции образования $\mathrm{ZnS}$ $k_{\text {пр }}$ использовали соотношение, характеризующее состояние равновесия, 
$k_{\text {пр }} / k_{\text {обр }}=x_{\infty} /\left(C_{0}-x_{\infty}\right)$, где $C_{0}-$ начальная концентрация $\mathrm{ZnSO}_{4}$ в растворе.

\section{Результаты и обсуждение}

На рис. 1 представлены типичные кинетические кривые, снятые в условиях контролируемой поверхности при температуре 363 K, начальной концентрации $\left[\mathrm{N}_{2} \mathrm{H}_{4} \mathrm{CS}\right]=0,1$ моль/л и $S=24500 \mathrm{~cm}^{2} /$ л.

Процесс образования $\mathrm{ZnS}$ считался законченным, когда достигалось равновесное значение остаточной

\begin{tabular}{l|c|c|c|c}
\multicolumn{1}{c|}{ Компонент } & $\mathrm{ZnSO}_{4}$ & $\mathrm{En}$ & $\mathrm{N}_{2} \mathrm{H}_{4} \mathrm{CS}$ & $\mathrm{NaOH}$ \\
\hline $\begin{array}{l}\text { Кажущийся частный порядок реакции (1) } \\
\text { по компоненту } n_{i}\end{array}$ & 1,0 & $-1,9$ & 1,2 & 0,3
\end{tabular}

концентрации соли цинка в растворе: горизонтальный участок на кинетической кривой. Результаты графического расчета $k_{\text {пр }}$ и $k_{\text {обр }}$ реакции (1) для концентраций En 0,15 и 0,20 моль/л. Результаты расчета $k_{\text {пр }}$ и $k_{\text {обр }}$ для концентраций En 0,1; 0,15; 0,20 и 0,25 моль/л показывают (рис. 2), что с увеличением концентрации En $k_{\text {пр }}$ уменьшается, следовательно, уменьшается и скорость реакции. С увеличением концентрации комплексующего агента уменьшается концентрация свободных ионов $\mathrm{Zn}^{2+}$, что замедляет скорость реакции.

По экспериментальным значениям $k_{\text {пр }}$ при различных начальных концентрациях $\mathrm{ZnSO}_{4}$, En, $\mathrm{N}_{2} \mathrm{H}_{4} \mathrm{CS}$ и $\mathrm{pH}$ можно определить порядок реакции по каждому компоненту. Расчет кинетических порядков реакции по компонентам проводили по уравнению $\lg k_{\text {пр }}=\lg k_{i}+n_{i} \lg C_{i}$, которое в координатах $\lg k_{\text {пр }}-\lg C_{i}$ представляет прямую линию с угловым коэффициентом $n_{i}$. Графическое решение этого уравнения для определения порядков реакции по компонентам En, $\mathrm{N}_{2} \mathrm{H}_{4} \mathrm{CS}$ и $\mathrm{NaOH}$ представлено на рис. 3-5.

Таким образом, в результате кинетических исследований установлено, что скорость реакции (1) пропорциональна концентрациям компонентов реакционного раствора, которые входят в кинетическое уравнение со следующими показателями степени:

По найденным значениям кажущейся $k_{\text {экп }}$ константы скорости была рассчитана истинная $k^{\prime}$ константа скорости гетерогенной реакции образования ZnS при температуре $363 \mathrm{~K}$, отнесенная к единице поверхности твердой фазы ZnS и единице концентраций каждого компонента с учетом частных порядков реакции:

$$
k^{\prime}=\frac{k_{\text {эксп }}}{S C_{E n}^{-1,9} C_{T M}^{1,2} C_{\mathrm{OH}^{-}}^{0,3}} .
$$

Полученные по уравнению (5) данные показывают, что при изменяющихся концентрациях компонентов реакционной смеси константы скорости реакции $k$ остаются постоянными в пределах ошибки эксперимента. Среднее значение $k^{\prime}$ составляет $(3,69 \pm 0,13) \times$ $\times 10^{-7} \pi^{0,6} \cdot$ моль $^{0,4} \cdot$ мин $^{-1} \cdot \mathrm{cm}^{-2}$ при $363 \mathrm{~K}$.

С целью определения экспериментальной зависимости скорости реакции сульфидообразования от температуры была проведена серия экспериментов при температурах 358, 363 и 369 K, что позволило графически (рис. 6) рассчитать 


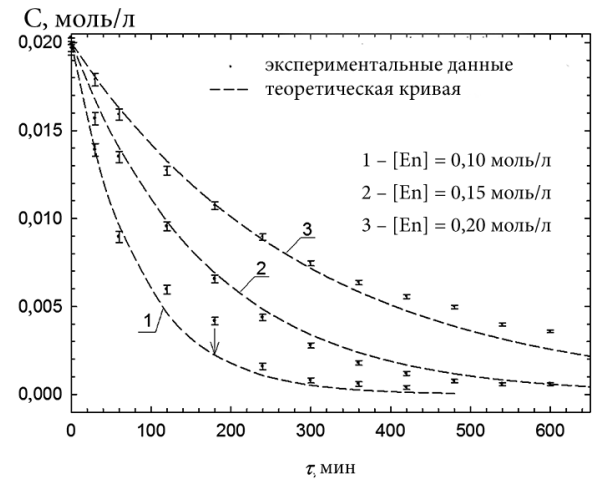

Рис. 1. Зависимость скорости реакции образования ZnS от концентрации этилендиамина En. Кинетические кривые сняты в условиях контролируемой поверхности $S=24500 \mathrm{~cm}^{2} /$ л при температуре $363 \mathrm{~K}$ и начальной концентрации $\left[\mathrm{N}_{2} \mathrm{H}_{4} \mathrm{CS}\right]=0,1$ моль/л. Теоретические кривые рассчитаны по уравнению (6)

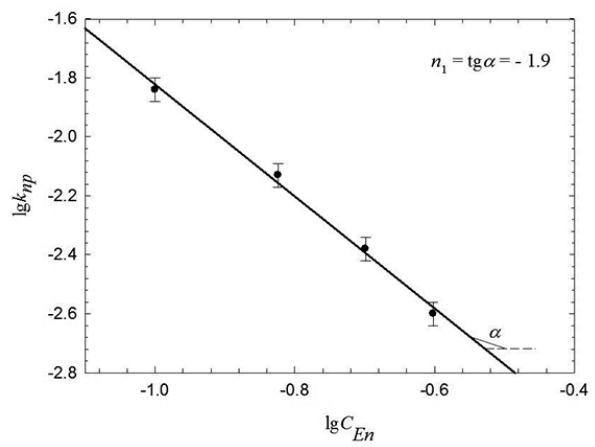

Рис. 3. Графическое определение частного порядка $n_{1}$ реакции образования $\mathrm{ZnS}$ (1) по этилендиамину. Реакцию проводили в условиях контролируемой поверхности $S=24500 \mathrm{~cm}^{2} /$ л при температуре $363 \mathrm{~K}$ и

$$
\left[\mathrm{N}_{2} \mathrm{H}_{4} \mathrm{CS}\right]=0,1 \text { моль/л }
$$

энергию активации процесса по уравнению Аррениуса: $\lg k^{\prime}=\lg k_{0}-(E / 2,3 R T)$, которая составила $E=84,5 \pm 0,5$ кДж/моль. Найденное значение энергии активации показало, что процесс образования сульфида цинка в системе не лимитируется стадией диффузии, поскольку для диффузионных процессов характерны

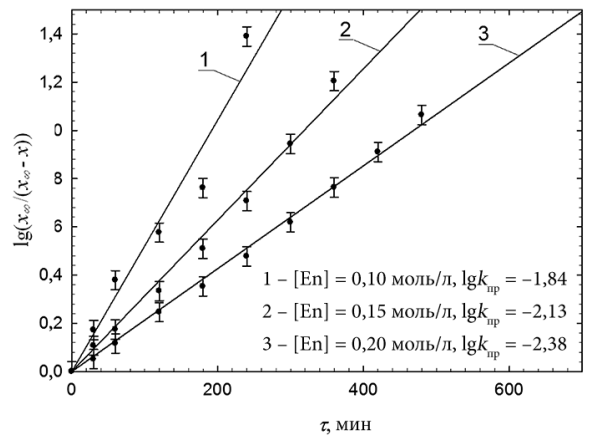

Рис. 2. Графическое определение констант скорости $k_{\text {пр }}$ и $k_{\text {обр }}$ процесса $(1)$ по уравнению двухсторонней реакции первого порядка (4). Процесс (1) проводили в условиях контролируемой поверхности $S=24500 \mathrm{~cm}^{2} /$ л при температуре $363 \mathrm{~K}$ и $\left[\mathrm{N}_{2} \mathrm{H}_{4} \mathrm{CS}\right]=0,1$ моль/л

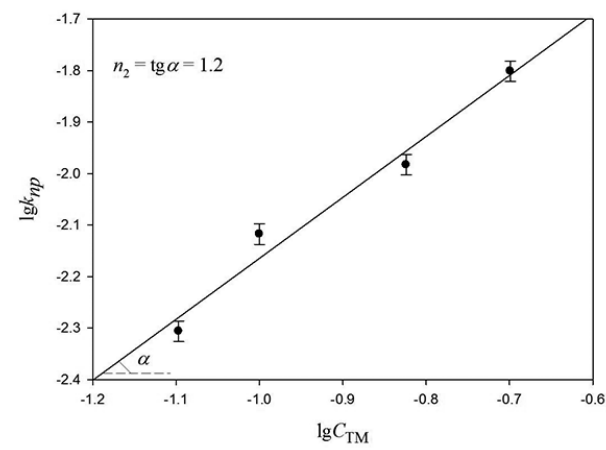

Рис. 4. Графическое определение частного порядка $n_{2}$ реакции образования $\mathrm{ZnS}$ (1) по тиомочевине. Реакцию проводили в условиях контролируемой поверхности $S=24500 \mathrm{~cm}^{2} /$ л при температуре $363 \mathrm{~K}$ и $[\mathrm{En}]=0,15$ моль $/$ л

малые значения энергии активации от 8 до 30 кДж/моль [15]. Предэкспоненциальный множитель уравнения Аррениуса рассчитан по истинной константе скорости при 363 К и при известном значении энергии активации $E: k_{0}=$ $=5,39 \cdot 10^{5}$ моль $^{0.4} \pi^{0.6} \mathrm{~cm}^{-2} \mathrm{Mин}^{-1}$. 
В результате проведенного исследования установлено, что процесс образования ZnS (1) описывается формальным кинетическим уравнением:

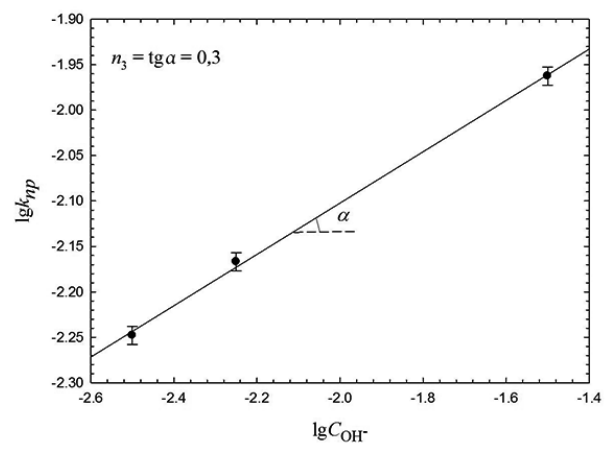

Рис. 5. Графическое определение частного порядка $n_{3}$ реакции образования $\mathrm{ZnS}$ (1) по $\mathrm{OH}^{-}$-ионам. Реакцию проводили в условиях контролируемой поверхности $S=24500 \mathrm{~cm}^{2} /$ л при температуре $363 \mathrm{~K}$ и $\left[\mathrm{N}_{2} \mathrm{H}_{4} \mathrm{CS}\right]=0,1$ моль $/$ л

$$
\begin{aligned}
w & =5,39 \cdot 10^{5} \exp \left(-\frac{84500}{8,3147}\right) \times \\
& \times S C_{E n}^{-1,9} C_{T M}^{1,2} C_{\mathrm{OH}^{-}}^{0,3}\left(C_{0}-x\right) .
\end{aligned}
$$

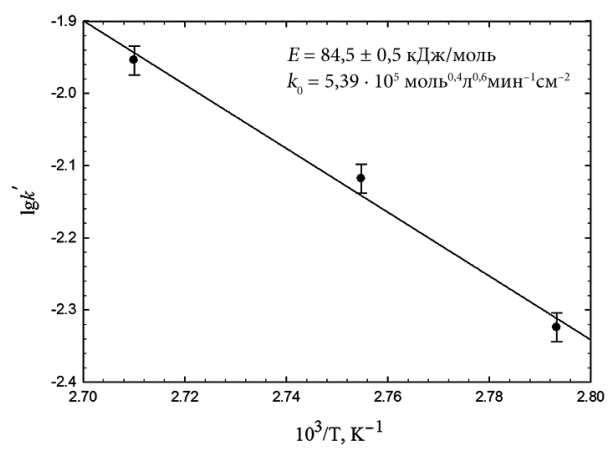

Рис. 6. Графический расчет энергии активации процесса химического осаждения $\mathrm{ZnS}$ (1) по уравнению Аррениуса

\section{Заключение}

Таким образом, в выбранных в данной работе условиях скорость процесca (1) слабо зависит от величины $\mathrm{pH}$, что объясняется буферным действием этилендиамина, зависит от концентрации осадителя (тиомочевины) и уменьшается с увеличением концентрации лиганда (этилендиамина) из-за снижения концентрации свободных ионов цинка в растворе. Расчет теоретических кинетических кривых по уравнению (8) показывает удовлетворительное описание полученных экспериментальных данных (рис. 1), что позволяет рекомендовать его для расчета скорости образования $\mathrm{ZnS}$ в водных щелочных растворах диамида тиоугольной кислоты.

\section{References}

1. Monroy E., Omnes F., Calle F. Wide-bandgap semiconductor ultraviolet photodetectors. Semicond. Sci. Technol. 2003;18(4):R33-R55. DOI: 10.1088/02681242/18/4/201.

2. Kroeger F. A., Hellingman J. E. Chemical proof of the presence of chlorine in blue fluorescent zinc sulfide. J. Electrochem. Soc. 1949;95(2):68-69. DOI: 10.1149/1.2776738.

3. Chen R., Lockwood D. J. Developments in luminescence and display materials over the last 100 years as reflected in electrochemical society publications. J. Electrochem. Soc. 2002;149(9):S69-S78. DOI: 10.1149/1.1502258. 
4. Quan Z., Yang D., Li C., Kong D., Yang P., Cheng Z., Lin J. Multicolor tuning of manganese-doped ZnS colloidal nanocrystals. Langmuir 2009;25(17):10259-10262. DOI: 10.1021/la901056d.

5. Peng W. Q., Cong G. W., Qu S. C., Wan Z. G. Synthesis and photoluminescence of ZnS:Cu nanoparticles. Optic. Mater. 2006;29(2-3):313-317. DOI: 10.1016/j.optmat.2005.10.003.

6. Debenham M. Refractive indices of zinc sulfide in the $0.405-13-\mu \mathrm{m}$ wavelength range. Appl. Opt. 1984;23(14):2238-2239. DOI: 10.1364/AO.23.002238.

7. Park W., King J. S., Neff C. W., Liddell C., Summers C. J. ZnS-Based photonic crystals. Phys. Stat. Sol. (b) 2002;229(2):949-960. DOI: 10.1002/1521-3951(200201)229:2<949::AID-PSSB949>3.0.CO;2-K.

8. Nanda J., Sapra S., Sarma D. D. Size-selected zinc sulfide nanocrystallites: synthesis, structure, and optical studies. Chem. Mater. 2000;12(4):1018-1024. DOI: 10.1021/ cm990583f.

9. Zhao Y., Zhang Y., Zhu H., Hadjipanayis G. C., Xiao J. Q. Low-temperature synthesis of hexagonal (wurtzite) ZnS nanocrystals. J. Am. Chem. Soc. 2004;126(22):68746875. DOI: $10.1021 / \mathrm{ja} 048650 \mathrm{~g}$.

10. Delmon B. Kinetics of heterogeneous reactions. Trans. with fr. N. M. Bazhina, E. G. Malygin, V. M. Berdnikov under the editorship of V. V. Boldyrev. M.: Mir. 1972, 554 p.

11. Kitaev G. A., Uritskaya A. A., Yatlova L. E., Mirolyubov V. P. Deposition of zinc sulfide from a solution of N-allylthiourea. Russ. J. of Appl. Chem. 1994; 67(10):16121615.

12. Uritskaya A. A., Kitaev G. A., Belova N. S. Kinetics of cfdmium sulfide precipitation from aqueous thiourea solutions. Russ. J. of Appl. Chem. 2002;75(5):864-865.

13. MatWeb: Material property data [Электронный pecypc]: Data sheets for over 87,000 metals, plastics, ceramics, and composites / Copyright 1996-2011 by MatWeb, LLC. Режим доступа: http://www.matweb.com/index.aspx, свободный.

14. Haimova I. M., Atlava L. E., Uritskaya A. A., Kitaev, G. A. Investigation of kinetics of chemical vapor deposition of zinc sulfide from solutions of allithiourea. Dep. VINITI, № 859-XII-88.

15. Zakharyevskii M. S. Kinetics and catalysis. L., Publishing house of Leningrad University, 1963, $314 \mathrm{p}$.

Cite this article as (как цитировать эту статью):

A. A. Uritskaya, N. S. Kozhevnikova, T. V. Yakubova. Kinetics of chemical deposition of zinc sulfide ZnS. Chimica Techno Acta. 2016;3(2):121-133. DOI: 10.15826/ chimtech.2016.3.2.009. 